\title{
Towards illiberal conditioning? New politics of media regulations in Poland (2015-2018)
}

Paweł Surowiec, Magdalena Kania-Lundholm \& Małgorzata WiniarskaBrodowska

To cite this article: Paweł Surowiec, Magdalena Kania-Lundholm \& Małgorzata WiniarskaBrodowska (2020) Towards illiberal conditioning? New politics of media regulations in Poland (2015-2018), East European Politics, 36:1, 27-43, DOI: 10.1080/21599165.2019.1608826

To link to this article: https://doi.org/10.1080/21599165.2019.1608826

\section{Published online: 06 May 2019.}

\section{Submit your article to this journal $\asymp$}

山ll Article views: 317

Q View related articles $\sqsubset$

View Crossmark data $־$ 


\title{
Towards illiberal conditioning? New politics of media regulations in Poland (2015-2018)
}

\author{
Paweł Surowiec (D) ${ }^{a}$, Magdalena Kania-Lundholm $\mathbb{D}^{\mathrm{b}}$ and Małgorzata Winiarska- \\ Brodowska (iD) ${ }^{\mathrm{c}}$ \\ ${ }^{a}$ Department of Journalism Studies, University of Sheffield, Sheffield, UK; ${ }^{b}$ Department of Sociology, Uppsala \\ University, Uppsala, Sweden; ' Institute of Journalism, Media and Social Communication, Jagiellonian \\ University, Cracow, Poland
}

\begin{abstract}
In this article, we examine how media policy changes aid dedemocratisation in Poland. Unfolding the logic underpinning the new politics of media regulations, this article argues that media policy paints a nuanced picture of democratic backsliding. Our Foucault-inspired discourse analysis of media policy archive focuses on the rise of illiberal trends at the cross-roads of the Polish hybrid media system, democracy and society. We find these trends display the features of centralisation of power, cultural politics, political partisanship and social polarisations. We explain these notions, using the concepts of "executive aggrandisement" and "politicisation" of public service media sector.
\end{abstract}

\section{ARTICLE HISTORY}

Received 11 November 2018 Accepted 15 April 2019

\section{KEYWORDS}

Poland; governmentality; public service media policy; media governance; illiberal trends

\section{Introduction}

This article focuses on the process of public media policy-making in Poland. It explores the interplay between political trends, media governance and ways in which their dynamics re-define state-citizens relations. Following the appointment of the Law and Justice (org. Prawo i Sprawiedliwość, abbr. PiS) majority Government in October 2015, laws were put forward, re-setting orientation for public media policy which, in turn, shook up public media sector. Subsequently, the Government was widely criticised for deteriorating standards of democracy. Poland is one of the most prominent cases, often compared to Hungary, of how political actors adapt fast-paced policy-making undermining democratic governance (Cianetti, Dawson, and Hanley 2018; Hanley and Vachudova 2018). These trends of democratic backsliding, which according to Bermeo $(2016,5)$, are "often used, rarely analyzed" comprise of multiple processes and agents, and "the state-led debilitation or elimination of any of the political institutions that sustain an existing democracy". Since 2015, sliding backwards in Poland implies that a political actor that won the parliamentary majority aims to concentrate executive control over public institutions.

Putting forward and introducing 2015-2016 public media policies were symptomatic of the PiS Government's governance style and, after a constitutional crisis, their introduction furthered public concerns about illiberal trends. Arguably, this sensu largo approach to 
democratic governance, unfolding in different areas of politics, goes beyond the scope of this article. We do, however, recognise that the parliamentary opposition and civic organisations in Poland alerted public opinion to threats associated with media policies put forward by the PiS. For the purpose of this article, however, we take sensu stricto approach to public media policy and, while interested in social change stemming from it, our departure point is the struggle over the process of policy-making. Our main focus is on the 2016 "Big Media Act", but we refer to the 2015 "Small Media Act" turning the PiS's "good change" manifesto into public media policy.

We explore how changes to the orientation of media policy emerging in Poland since 2015 align with illiberal trends in politics and, in turn, translate into the architecture of a particular public media space. Keeping in mind that "media policy creates the communicative space within which all public and decision-making discourses take place" (Braman 2004, 169), our analytical foci are the governance features that the PiS Government's media policy introduces, including their political background, cultural and ideological underpinnings and social changes stemming from the public media as a space for political communication. Following Garnham's $(1998,210)$ definition of media policy as "the ways in which public authorities shape, or try to shape, the structures and practices of the media", we contribute to the debate on media policy research beyond endogenous trends in the field (Bardoel and d'Haenens 2008) and reveal new, exogenous pressures on Poland's hybrid media system unfold in public media sector. We make sense of public media policy changes by asking the following research questions:

RQ1: What public service media policy changes have been put forward and introduced?

RQ2: What are the key governance features underpinning these media policies?

RQ3: How do political trends in Poland link with the making of public service media policies?

RQ4: How do, if at all, media policies instigate social changes impacting citizens in Poland?

To address these questions, we contextualise our analysis in existing academic literature on illiberal trends in politics as well as research focusing on public media policy research in Poland. We then propose a conceptual framework, which is followed by methodological underpinnings of our analysis. Presentation of key insights emerging from policy analysis is, finally, followed by discussion of our findings, and their significance to democracy and citizens in Poland.

\section{Sleep-walking into illiberalism}

Given that illiberal trends have emerged in Europe in various settings in Hungary, Russia and the United Kingdom, it is safe to assume that illiberalism is a trend transcending different types of political regimes and institutions. The political powers turning and twisting this trend are complex and, in Poland, one of its early manifestations unfolded at the crossroads of politics, media policy and public service media, springing concerns about democratic governance. The early voices pointing to the treats associated with illiberal trends did not, however, emerge in media studies. Political science foregrounded them a while ago. For example, Puchalska $(2005,816)$ argues that "authoritarian, exclusive and undemocratic style of politics of the first years of reforms, squandered social trust and undermined the 
potential which this democratic revival represented (...)". Shields $(2015,669)$ speaks about "a subtle appeal to neo-liberal market reforms in amongst the populist and illiberal politics that seek to replace existing class based representative institutions and practices". Kubik (2012, 80) problematises illiberalism "as a political option that is based on three principles: (1) populism, (2) (organizational) antipluralism, and (3) ideological monism". Most recently, Grzebalska and Pető $(2018,167)$ conceptualised institutional illiberal changes taking place in Poland and Hungary as "polypore state" to theorise how illiberal elites in Hungary and Poland appropriate resources from existing policies and funding infrastructure of the European Union (the EU). In the light of the conducted literature review, it transpires that media studies focus on democratisation rather than de-democratisation (Sparks 2008). Subsequently, research has placed Poland on the map of analysis of media "oligarchisation" (Štětka 2012), media commercialisation (Dobek-Ostrowska and Głowacki 2015) media convergences (Szczepaniak 2011) and media fragmentation (Zielonka 2015).

The market presence of digital media companies, changing patterns of media consumption, new ways of making of political news, and hyper-campaigning has made the logic of hybrid media in Poland more pronounced than ever before. Whilst this process is recognised as an explicit feature of media systems in the CEE region (Surowiec and Štětka 2017), the politics of media policy remains under-studied. The bulk of existing research focuses on the frameworks regulating the interactions between "new" and "old" media (Gulyás and Hammer 2013). The research on public media reveals (Stępka 2010) a few pronounceable tendencies towards, on the one hand, commercialisation and, on the other hand, ongoing political interference into the sector (Lauk 2009). Undertaking the task of exploring public media policy, Jakubowicz's (2004) normative analysis suggests that policy-makers in Poland tend to manoeuvre between mimetic and atavistic public service media policies orientations. Unlike in this normative conceptualisation of media policy, we question this predominantly binary dynamics, and provide contextspecific evidence of multi-dimensional tensions and power relations underpinning public media policy-making.

\section{Public media policy research}

Over the past decades, the analysis of media policy in Poland was inextricably tied with the process of democratisation (Goban-Klas 1990; Dobek-Ostrowska 2006, 2011). Research on media systems in the post-Soviet Central Eastern Europe has focused on media policy and the regulatory framework concerning issues such as ownership, media freedom and media accountability (Gross 2002; Paletz and Jakubowicz 2003; Jakubowicz and Sükösd 2008). This scholarship acknowledges that democratisation of Polish media system took unpredictable turns in comparison to other public institutions. In the field of media policy research, the Polish media system has been described as particularly volatile to political interference from the National Broadcasting Council (org. KRRiT) (Głowacki 2008). Both empirical studies and descriptive accounts of media policy demonstrate that public media and the governing body were of particular interest to Polish political parties, which either aimed at shaping media regulations (Goban-Klas 1996) or, using politically motivated appointments, strived to control the KRRiT.

Media policy research tends to highlight media pluralism as the main pillar for the continuity of democratisation in Poland's media system (Klimkiewicz 2017). Other studies 
provide more complex picture. For instance, Sparks $(2008,13)$ argues that in contrast to the official media of the state socialist era, media in Poland is marketised and plural. However, at the same time, it remains under the watch of elite groups, instead of adapting its orientation towards publics.

Apart from party politics, the orientation of public media policy has been shaped by foreign ownership and, in the absence of strong journalistic cultures, is filled by corporate cultures of transnational media organisations (Gross 2004). Consequently, the above dynamics surrounding public media policy define the features of political communication culture including: accusation of incompetence between politicians and journalists, struggle for professional distance between these two types of actors and breaches to rules at the interactions between them (Pfetsch and Voltmer 2012). These insights accentuate the significance of media governance for democracy in Poland. However, with the exception of the article by Głowacki (2015), arguing that more needs be done to understand ties between media regulations and trends in politics, there are no studies exploring links between media policy and illiberal trends in politics.

\section{Conceptual framework: governmentality, media policy and political disruption}

Our framework rests on three pillars. To aid the analysis of the politics of public media policy, we draw from the discursive tradition of media policy research (Streeter 2013). First, given that we are interested in the shifts in the orientation of regulations, we draw form the conceptual oeuvre of media policy. We use the discursive notion of media policy in conjunction with Foucault's "governmentality". For Foucault $(1982,790)$ "to govern, in this sense, is to structure the possible field of action of others". There are two aspects of governmentality that are relevant to our analysis. The former is the principle method for the rationalisation of governmental practices (Foucault 1989). The latter, in Foucauldian tradition, "seeks in its own ways the integration of the self-conduct of the governed into the practices of their government and the promotion of correspondingly appropriate techniques of self" (Burchell 1996, 29).

Second pillar refers to Freedman's $(2008,14)$ concept of "media governance". It is broader than statutory media regulation and implies the "sum total of mechanisms, both formal and informal, national and supranational, centralized and dispersed, that aim to organize media systems". According to Puppis $(2010,139)$ this concept is of substantial value for media policy research as "it is a new way of describing, explaining, and criticizing the entirety of forms of rules that aim to organize media systems". It allows bridging the Foucauldian notion of governmentality with public media as "technology citizenship" (Nolan 2006, 233). This approach proposes that citizens' identities are made up by the interactions between different authorities, different ways of understanding the concept of "public", and in empirical terms, to demonstrate ways in which media policies approach Polish citizens and collective governance.

Third pillar of our framework, is in line with the current advancements in the field of political communication, and extends to research on media policy. Following the recent developments on the disruptive features in political communication (Bennett and Pfetsch 2018, 244), the process that is triggered by "attacks on traditional media as elitist", we strive to move the debate about Poland's public media beyond the normative 
assumptions about democratising the power of public media. We are interested in the implications that the media policy has for political conditioning (Lilleker 2014) of citizens as well as inquiring about the role policy has in the re-setting of architecture for political communication in Poland.

\section{Discursive archive and analytical approach}

In this article, we employ an interpretive approach to media policy, which invites the study of policy as part of the specific socio-cultural contexts rather than technocratic expertdriven endeavour. In epistemic terms, media policy is not analysed in the vacuum, but rather as entangled in political and cultural struggles over meanings associated with its zeitgeist. As Streeter $(2013,495)$ suggests: "discoursively oriented work on policy has become a contributor to understanding the social construction of modern institutions". Discoursive struggles over meaning are best captured through the study of transformations. In this respect, the Foucauldian approach (1972) to discourse is the one enabling us to address research questions $($ see, 2 ) by focusing on the process of policy-making, its socio-political contexts and social change.

Discourse is a set of statements, which provides language for talking about and representing knowledge, objects, subjects and practices. Our aim is also to explore how issues of media policy are entangled with often value-laden questions of subjectivities between "public", "civic" and "national" interests. The Foucauldian approach enables to focus on how key institutions of media policy-making in Poland construct their knowledge subjects, how the policy orientation impacts public media and how, in return, those translate into social changes. It also allows us to focus on the types of statements which are foregrounded, backgrounded and those that are silenced.

Our sampling is based on the principles of politically significant cases selected on the basis of their significance to the direction of changes presented by public media policy. Purposive sampling is a common place in the studies on public policy (Sam 2019) or media policy (Nolan 2006). In this study, however, it is particularly useful as it enabled us to focus on the making of public media policies of a landmark significance, and the one that attracted a lot of attention among social groups and think-tanks, governments, the EU, and journalists alike (Chapman 2017). The selection of the regulatory documents making up the analysed public media policy orientation was guided by policy-makers and, in that sense, we followed their making.

The archive of 119 documents (ranging from 1 to 51 pages) includes detailed minutes of proceedings from the hearing on media policy; legal acts, policy proposals, media statements, press releases, reports (e.g. think-tanks) and commentaries by media industry actors. We have identified the following strands making up the discourse on the emergent public media policy orientation: contextualisation strand; legitimisation strand (consultancy documents, policy positions); expert comments strand (e.g. though leadership); the law strand (the legal Acts) - statements of which each are interconnected. Additional in-depth reading of the archive led us to the identification of four main themes, which in Foucauldian terminology are called "dispositives". Dispositives are defined as formations with the dominant strategic function of responding to an urgent need at a given historical moment (Foucault 1980). These include: the structural and governance changes to the public media sector; cultural principles for media governance, and finally, the impact of 
policy on political communication and its significance for citizens. We report them as findings in relation to our research questions.

\section{Re-positioning of public service media}

In this section we report findings pertaining to the policy changes put forward by policymakers (RQ1). In here, we focus primarily on the foregrounded statements present in the legitimising strand of the discourse on the 2016 "Big Media Act". This policy was put forward by a group of MPs as a three-tier regulation on national media, audiovisual fee and executive decrees (Broadcasting and Culture Commission 2016). Of the three Acts submitted to the Parliament on 21 April, 2016, none was passed in the original shape, and another legislation - the 2016 "National Media Council Act" - was put forward to replace the 2015 "Small Media Act". The "National Media Council Act" was passed by the Parliament on 22 June 2016 as a measure to regulate the appointments of executives and the boards of public service media. This Act filled the vacuum for some regulations articulated in the draft of the "Big Media Act", but was met with widely public criticism. Its draft proposal assumed that the National Media Fund would appoint executives and the boards of directors (Articles 22-25), establish the Social Programming Councils (Articles 29-38) and set up the National Media Council (Articles 39-47). The Chair of the Council was given both concession to lead the appointments of directors of public media and governance of the National Media Fund. Given that the 2016 Act policy has not been introduced, the Act on National Media Council was introduced to solve procedural issues (see, Appendix).

This Act aimed to regulate the scope of the National Media Council, its statutory mandate, responsibilities, office of the Chairman, accountibilty and the appointment of public service media executives as well as supervisory roles over them. The changes emerging in the National Media Council Act attempted to codify media policy changes, also explicit in the public hearing on the 2016 "Big Media Act". By the passing of this Act, the status of public service media as the state-owned enterprises affiliated with the Treasury has been sanctioned and provided the basis for bringing the public service media closer to the Polish state structures and party politics. Unlike in the 2015 "Small Media Act", which had triggered staffing changes in the sector, the National Media Council was given the power to appoint the boards and executives of public service media. This collegiate body, made up of three appointees of the Parliament and two of the President, was to choose the candidates from the parliamentary opposition. While this solution has moved the appointments away from the Treasury, it remained centred around party politics. Further, the opportunities for party control over the Council were explcit in the conflict of interest regulations (Article 5) allowing political actors such as MPs to become members of the National Media Council.

The structure of public service media, branded as "National Media", included the network of brodcasters: Polish Television ("TVP"); Polish Radio ("PR"), seventeen regional radio stations and the Polish Press Agency ("PAP") (Article 2). Within this outline, limited attention was paid to digital media technologies (Article 11, points 3-5). In addendum to the draft, the Act $(2016,33-34)$ aimed to address challenges associated with digitalisation in the production of "on demand" content, innovation in the production techniques and wider relations with digital media technologies users. These broad statements were 
highlighted by representatives of the Citizens' Pact for Public Media foregrounding that the proposed Act did not take the role of the Web-based technologies in public media seriously enough (Broadcasting and Culture Commission 2016, 33). Whilst the issues of digital media technologies had been brought up during the hearing, also suggestions were made to create a specialised "public service internet portal" that would embody the public service mission. However, these have not been taken on board and the links between public media and other digital technology providers have not been addressed in this particular policy proposal.

\section{Step towards "statism"}

This section focuses on the statements that identify the key governance features of the public media policy (RQ 2). Among the themes legitimising the proposed policy, there was a prominent commitment to centralise public media closer to the Polish state. Of the three Acts, "National Media Act" proposed changing strategic branding of the network from "public" to "national" media (Articles 1-2). This was mirrored in the public mission statement. Despite the opposition's calls to ensure media independence, the proposal provided additional controls, particularly by the National Media Council and the National Media Fund (Article 7). These bodies constituted an additional layer of bureaucracy, moving public media away from the existing regulator, the KRRiT. This re-positiong was further manifested by turning the network of National Media and their governing bodies into legal entities (Article 2) as opposed to them being the property of the Treasury. This move aimed at changing their status as limited companies, the legal status of which was described as "fetishised" in the era of post-transformation (National Media Act 2016, 24). The Polish Press Agency was aligned closer to the state, as it has received a status of a national institution and it was compelled to disseminate all news releases of governing institutions.

With regards to establishing of regulatory bodies, the function of which was to deliver the mission of public service brodcasters, the draft proposed (Articles 39-47) the introduction of the National Media Council, a body responsible for the appointments of directors of National Media and setting up of the Social Programme Councils (Articles 29-38). The National Media Council was supposed to have taken over some of the responsibilities of the Ministry of Treasury - particularly the appointments of the directors of National Media boards and executives by the Chair of the National Media Council (Articles 2225). The safeguarding role over the public mission was tasked to the Social Programming Councils, appointments to which were made from candidates who do not directly participate in political life. However, for instance, the Catholic Church and labour unions were explicitly listed (Article 29) as being the potential sources for appointees, which points to an impact these institutions have on the politics in Poland, and traditionalist political legacy they still carry. Setting up of those bodies was deemed contestable, because of their undefined relationship to the National Braoadcasting Council (org. "KRRiT"), the governing body and a constitutional institution of Polish democracy. For example, during the public hearing, their introduction was criticised by the representative of the Polish Chamber of Digital Communication as unconstitutional. Given the advancing trend of media convergences, suggestions were made to expand the regulatory scope of the KRRiT with the aim to integrate institutions rather than to split them (Broadcasting and Culture Commission 2016, 22-23). 


\section{Financial governance}

The policy proposal placed the National Media Fund in charge of the budget of the National Media (Article 48). This body was to perform a key role in the execution of the budgetary policy of public media. The National Media Fund was deemed responsible for financial reporting to the Ministry of Culture and Heritage and to the Ministry of Finance. The financial resources of the National Media Fund were to entirely come from public funding, paid alongside energy bills as a audiovisual licence fee. The proposal allowed donations to support the public mission of National Media. The Fund was to be exclusively supported by the state. This regulation was uttered as a policy requirement. For example, Maciej Strzembosz of the Chamber of Audiovisual Producers argued for the reduction of adverting as a revenue for public media, whereas Tomasz Truskawa of the Freedom of Speech Association argued for the reduction of market competition on public media. In the public hearing, the CBOS (2016) poll, according to which $60 \%$ of Poles do not approve of additional charges, was brought up.

However, the financial situation of the National Media allowed diversification of founding sources. They were to come from the National Media Fund, copyrights fees, revenues from news services, advertising revenues, sponsored programming, income from affiliated companies, and donations from the state budget (Articles 18, 51 and 52). These governance solutions created financial regime based on the mixture of public and commercial funding. Such finance regime, however, aimed to set the dominance of public funding, which, stood in the opposition of public opinion poll on the issue. The National Media Council was both holding public media finances and act as a supervisory body of the National Media (Big Media Act 2016).

\section{Ideological revisionism}

In this section, we aim to answer RQ3 by exploring the backgrounded and silenced statements pointing to the cultural-ideological underpinnings of policy changes put forward as media policy orientation since 2015. We locate them in the context of the public responses that followed those changes. Further, the relationship between media policy and political trends is explored in order to understand whether, and if so, how, the recent political trends towards illiberalism manifest through the lens of media policy changes and civic reactions to them. The public media transformation under the PiS Government, already since the first time when the party was in power in 2005, has been mainly driven by the ambition to both repolonise public media and depoliticise it. Repolonisation (org. "repolonizacja") refers to the efforts aiming at increasing domestic ownership in Poland's financial sector. More specifically, in the media sector, it refers to a drive towards increasing domestic ownership on the media system, which in turn, implicitly, is likely to make media outlets provide favourable coverage of the current Government (Chapman 2017). In practice, it means the turn towards an institutional architecture, which supports ideological programme of the PiS and the Government's policies (see, 3).

Repolonisation takes place along depoliticisation, and the first attempt to depoliticise the public media was introduction of a temporary "Small Media Act" in 2015. Its goal was to terminate the mandate of the current members of the National Media and supervisory boards. In practice, this implied the marginalisation of the role of KRRiT, which 
meant to, as stated in the Polish Constitution (Sejm, 1997, Chapter 9, Art. 213) "safeguard the freedom of speech, the right to information, and the public interest in radio and television broadcasting". Instead of competitions organised by the KRRiT, executives and supervisory boards would be directly appointed by the Treasury Minister. This Act was put forward to depoliticise the public media, which according to the PiS, was serving as a propaganda mouthpiece for the formerly governing party, the Civic Platform (org. Platforma Obywatelska, abbr. PO). This attempt to change both the leadership and staff of the public media was a step towards more partisan control over the KRRiT. The "Small Media Act" was eventually superseded by the "National Media Council Act" in 2016.

\section{"Nationalising" public mission}

In practice the draft aimed to transform the existing public media model into a sector of a media system promoting the political and ideological programme of the Government by developing stronger ties between the state and public media (Klimkiewicz 2017). From cultural and ideological perspectives on this shift, particular attention deserves the modification of public service mission of the National Media. For instance, in Chapter 1, Article 3 of the Act contains provisions on the role and mission of public media, including what should be broadcasted. The main goal of public media, according to the Act, is to "preserve national traditions, patriotic and human values (...)" and "promotion of the Polish and world science and art" and "contributing to the spiritual needs of listeners and viewers". Some provisions include rather vague statements such as "creation of conditions for pluralistic debate about social affairs". The Article 4 states that broadcastings' institutions would pay attention to the "culture of the Polish language" and "respect Christian value system and universal ethical values".

In Article 9, the draft describes in 23 points the public mission of the media. Accordingly, the public media is obliged to "strengthen the national community and responsibility for the collective good" (point 2), "enrich historical awareness and counter misrepresentations of Polish history" (point 3), provide a "fair portrayal of diverse events in Poland and abroad" (point 5), "promote of free citizen and public opinion" (point 6), "to facilitate citizen and civic organizations' participation in public life through presentation of diverse opinions and positions and their right to social control and critique" (point 7). At the same time, the mission of public media is also to "portray family values and take steps to strengthen the notion of the family" (point 9). Article 11, point 3 also defines public mission of the media in terms of fulfilling of "civic, social, cultural, and educational needs of society and its elements". Interestingly, in a document substantiating the draft, it is stated that the Act would guarantee independence of the public media from a government and that the main task of institutions of National Media is to fulfil the public mission. The document states that in comparison with the previous 1992 public media policy, the newer version emphasises "strengthening of the national community and common good, historical awareness and knowledge about Poland abroad" (Article 9, points 2-4).

\section{Cultural underpinnings}

The changes to both leadership and staff of the public media prompted protests across Poland, including those organised by a social movement, the Committee for Defence of 
Democracy (the KOD). One of the key arguments of the PiS opponents was that the Government was introducing direct control over editorial policy and indirect control of media content in order to advance its partisan interests. Arguably, the ambition to depoliticise public media have brought the opposite effects. Part of the issue can be related to the fact that the PiS Government made an attempt to directly leverage the power of the public media to shape the public opinion that, in turn, could serve the governing party. Further, ad hoc consultations served as a measure to legitimise the actions undertaken by the PiS Government. In the afore-mentioned public hearing of the Broadcasting and Culture Commission, seventy-one speakers of non-governmental organisations met on 21 May 2016 to discuss the proposed policy changes. When it comes to the cultural-ideological principles underpinning the governance practices of policy-makers and public media, one can distinguish three topics raised during the hearing: the nature of the mission of public media, question of media independence as well as limited transparency in legislative process.

On the one hand, the mission of public media is rather vaguely described in the policy draft. For instance, several representatives of civic organisations took up terms such as "humanist values" and "national community" as taken for granted and not precisely defined. Also, the notions of "public" and "national" employed interchangeably in relation to media raise concerns about the shift towards partisan, local and anti-European direction of changes in Poland. Similarly, the draft received criticism for lacking statements that would clearly define the mission of public media in terms of pluralistic coverage, protection against hate speech and respect of minorities. The criticism also concerns the fact that a variety of terms used could be interpreted in multiple ways. On the other hand, for the PiS supporters and proponents of the new law, public mission of the media is tightly connected to the logic and mission of repolonisation of the media, which goes beyond the issue of increasing of the domestic ownership of public media sector. Instead, the mission concerns silenced statements, which relate to direct control over media content and editorial inner-working, and the idea to "bring back the media to the Polish nation".

Similarly, independence of public media has been widely questioned. Beside the problems of opaque appointment procedure and employment structure to the National Media Council, opponents brought up the absence of any legislative guarantees for journalists to secure their professional autonomy. In this context, the concept of depoliticisation was described as a cover up for strengthening the links between public service media and the practice of government propaganda. For policy-makers, however, the latter relates to the practice of decommunisation (org. "dekomunizacja") defined as dismantling of the legacies of the state socialism. More specifically, it relates to cleansing of the public media from old secret collaborators. Freedom of speech, or "real freedom of speech" as one of the public discussants put it, and pluralism are discursively employed by the Act's proponents as facilitators in the processes of decommunisation and depoliticisation. Limited transparency in the introducton of the media policy was third among the most prominent topics, often brought up by their opponents. It relates to the unusual speed of the process as the draft was introduced by the Speaker of the Parliament, not via public consultations or "thorough and inclusive public debate" (Klimkiewicz 2016). Additionally, the problem that National Media Council is not a constitutional body with executive powers points to the blurring of boundaries between party politics and policy. 


\section{Citizens (re-)socialisation and disrupting political communication}

In this section, we address the RQ4 focusing on the ways in which media policy changes set the architecture for political communication for citizens in Poland. The mixture of financial priorities and cultural shift have underpinned themes defining the ways in which the nexus of state-public media-citizens was approached by policy-makers, and consequently acted as an incentive aimed at shifting social relations. In relation to politics, Lilleker $(2014,65)$ defines conditioning as a "learned responses to external stimuli that determine cognition and behaviour".

In the proposed policy, the audiovisual licence fee meant to incentivised citizens to contribute further to the mission of the public media, despite limited support for new regulations in this area. In turn, this regulation was met with concerns. For example, during the hearing of the Broadcasting and Culture Commission (2016, 11-37) statements by speakers for the Citizens of Culture exemplify this policy position: "public media is supposed to be civic media, but civic does not mean that the only citizens' right in this definition is the right to pay fees and nothing else". This sentiment echoed beyond financial regulations.

Indeed, public media can be seen as the broadcasting technology for collective governance. The cultural shift visible in the proposed policy is the preferred notion of "publicness" that explicitely foregrounds collective identities, while at the same time, silencing an inclusive notion of "civicness" defined in terms of individual identities. The collective identities were put ahead any individual identities, and this logic was extended to political conditioning. In the draft of the Act, two tasks of public media have been explicitely formulated. The first task was to contribute to the comprehensive socialisation of youth and the protection of children from demoralisation (Article 9, point 10), whereas the second task was to cooperate with authorities, churches and religious associations, public service organisations and other institutions acting for the common good and human good (Article 9, point 23). In the further part of Chapter 2, titled "Performing Public Mission", Article 15 deals with the media access of public service organisations and Article 18 with educational programms. In addition, the policy proposal carries a record regarding the preservation of family values.

The siginifier "national" was juxtaposed against the public mission of public media. Among the general provisions in Chapter 1, the emphasis was put on the public mission of National Media, the aim of which is, among others, to popularise forms of civicness (Article 3, point 2). In Chapter, 2 dealing with the public mission, Article 9 stipulates that one of their tasks is the formation of public opinion (point 6) and enabling citizens and civic organisations to participate in public life by presenting diverse views and exercising the right to control and social criticism (point 7). However, these provisions were drawn from the media policy codified back in December 1992. Whilst freedom of speech was highlighted in this policy proposal, the concerns were raised during the public hearing that public media sector is prone to delivery of government propaganda at home and abroad, and subjecting citizens to the dominant worldview through the prism of imposed, top-down, national traditions, patriotic and Christian values. The concerns about these tendencies unfolded in relation to citizens at home and diaspora communities as recipients of political communication by the National Media. The attempts to introduce mechanisms of control over public media by the state, blurring of boundries between 
media policy and editorial practices, had polarising effects. During the hearing, some speakers argued that "philosophy of the Act is based on media capture by one political party. This, in fact, would lead to the dramatic situation whereby public media, instead of being a space into which everyone can be included, would become another field of the deepening tensions" (Broadcasting and Culture Comission 2016, 11) or that "citizens finance the propaganda and comfortable lifestyle of governing class, thus closing the circle of control over their lives" (Broadcasting and Culture Comission 2016, 37).

\section{Discussion}

The conceptual framework applied in this article has allowed us to approach media policy changes in Poland from the perspective of governance in terms of rationalisation of practices, but also as a process of governing the public. As findings reveal, the policy changes have had a rather disruptive impact on the process of political conditioning in Poland turning into the direction of illiberal trends in politics. Our findings point to the executive aggrandizement (see 2) as a particular type of democratic backsliding evidenced by the making of public media policy in Poland (Bermeo 2016). This process of disassembling of democratic governance is faciliatetd by legal means. In other words, backsliding takes place through elected officials and, because of that, poseses mandate of legitimacy. Keeping in mind that backsliding is not exclusively caused by emotions, oftentimes associated with populism, but rather rational and predictable reactions to policy and institutional changes, we argue that public media policy changes in Poland is used for the expansion of governmental power. In that regard, the politicisation of media policy is a re-occuring feature of illiberal conditioning. The previous PiS Coalition Government (2005-2007) introduced changes to "broadcasting law and imposed its own appointees to leading bodies" (Sparks 2008, 13). However, by setting up the National Media Council, policy-makers pushed the boundries of control over the appointments of public media executives.

Defined by centralisation of state power (Levy 2006), this approach demonstrates abuse of consensus. By bringing public service media closer to the state, the "Big Media Act" proposal and the subsequent "Act on the National Media Council", introduces "command and control" governance inspired by the statist imperatives instead of citizens' interests or social cohesion. In doing so, it undermines the KRRiT as a constitutional body. This breaking of the boundries of the self-governence towards the expanding political control was not only theoretical. For example, party politics played out via the National Media Council as the Sejm appointed Elżbieta Kruk, Krzysztof Czabański and Joanna Lichocka, the PiS nominees to the Council. The remaining appointees, Janusz Braun and Grzegorz Podżorny, were nominated by the opposition. Further, modus operandi of the Council shows favourism towards the PiS. In fact, their spin doctor, Jacek Kurski, was appointed as the director of "TVP"continuing the governance following his appointment under the framework of the "Small Media Act". Finally, the centralisation of state power can be illustrated by the new legislatory procedures introduced by the Government, namely: a high intensity of parliamentary proceedings over new public media regulations, the acceleration of the Sejm's hearings and public consultations, late votings adding to the overall impression that the PiS was trying to rush the legislative process.

Mindful of the fact that in hybrid media systems, news making is the process of "boundary-drawing, boundary-blurring and boundary-crossing" (Chadwick 2013, 184), we suggest 
the changes to media policy in Poland can be extended to "boundary-breaking" - dismantling of democratic rules governing public media. This logic of breaking and pushing the boundaries of the public media is linked to populist style through the creation of political demand to revisit media system in Poland, first public and later private media. This is a continuation of the ongoing trend, in which political actors do not inform the making of media policy on empirical evidence, but on the basis of political speculations, which, ex ante, assumes particular outcomes of the proposed public media policy without any explicit analysis of its design. This way, media policy in Poland is driven by the logic of conditioning of citizens to mechanisms for the creation of an institutional space designed on the principles of political monism (Kubik 2012). This emerging "illiberal bubble" can be defined as

an institutional and discursive space, the architecture and governence rules of which operate on the basis of state-centred relational set up geared towards conditioning of citizens to the vision of a public life inspired by anti-pluralism, seemingly non-contestable dominant values, celebrated ideological monism, and belief-driven features of public life amplified within a public media space.

Based on the nature of the analysed material and its relative novelty we cannot ascertain neither the immediate, short term impact of this policy nor the larger socio-political climate in Poland effected by it (e.g. protest organised by the KOD movement). However, the discourse approach employed in this article allows to understand the role of media policy in setting the architecture for media governance and political communication. With regards to cultural and ideological principles underpinning the governance practices of policy-makers, on a discoursive level, the public media is treated by the PiS Government as a "national good", and the property of the entire Polish nation. An attempt to control public media takes place through an employment of familiar cultural themes, tropes and narratives such as "national" and "common good" or "patriotic values". These familiar themes, tropes and narratives on collective identities are forms of imaginative identification with the discourses on nationhood (Barker and Galasiński 2007).

Arguably, policy-makers in Poland built on beliefs rooted in collective memories, cultural themes and values. This is explicit if we look at the notions of repolonisation, depoliticisation and decommunisation which all aim to declutter public life from "foreign" elements and, at the same time, constitute one of the main points of discursive struggle. Given that the Government pointed numerous times to media partisanship and political biases among journalists, the notion of "strong, independent public media" has been discoursively constructed in relation to that very bias, which existed over the years. In such light, the PiS could construct an image of not only a legal saviour of the public media service, but also a guardian of national values and community.

With regards to public media as a space for political communication between democratic institutions and citizens, the inclusion of the Polish Press Agency into the network of National Media, and extending a public mission status into this actor, strenghtens its position as a supplier of news. If considering the disruption of relations among media, democratic institutions and publics discussed by Bennett and Pfetsch (2018), in the context of the proposed media policy orientation, the disruption to political communication architecture emerges along the following lines: media independence, media pluralism, and disruption to transparency in the making of the policy.

It is worth noting that an important aspect of regulatory framework for policy-makers is socialisation of Polish youth, particularly in moral, national and communitarian sense. The 
media policy orientation goes hand in hand with other changes such as the one in the field of education. Polish youth are being conditioned to certain values, symbols, formulas (Lilleker 2014). This conditioning mechanism provides citizens, especially youth, with an institutional architecture for making sense of the world of politics. Interestingly, the draft document on National Media does not utter the phrase "civil society" a single time. Further, many abstract terms have been introduced to the draft, for example, "cooperation", but there are very few particular solutions to the issues of civic participation and social inclusion. For example, media access for minorities tend to be treated in an instrumental way. Although the utterance "specific needs of people with disabilities" appears in the Draft (Article 9, point 16), it does not require the public media to ensure a minimum representation levels of this social group. These regulations reinforce the logic of democractic representation by exclusion and incluson and ingrain them into the fabric of public media policy.

\section{Conclusions}

Since 1992, media policy has been debated as a linchpin of liberal governance, and a feature of democratisation in Poland. This article, however, demonstrates that democratisation is far from being a linear process. Our analysis unravels the dynamics of illiberal trends as an antipluralist process entangled in the making of public media policy and advancing rules for public media underpinned by tendency for ideological monism. To recap, the 2016 media policy was not fully implemented by the Government and the regulations included in "The Act on National Media Council" are still perceived only as a temporary. The PiS Government is still keen to introduce new regulatory frameworks for private media as well as to tackle issues surrounding "fake news". To that end, media policy continues to be a playground for the conditioning of Polish citizens to the style of politics, in which liberal media are targets of direct attacks, media policy mirrors revisionist tendencies in politics, and public media sector slides towards becoming a space for the re-enactment of party interests. The analysed policy is a manifestation of multi-dimentional illiberal trends. This process involves a combination of rational means, such as policy changes, on the one hand, and affective measures such as fetishised ideas of common good, on the other. Its iteration in the Polish contexts idolises the nation which, combined with the limiting of media freedoms, makes up the sensibilities of illiberalism (Kubik 2012).

Further, recent media policy change put forward via legal channels in the name of the nation and strong patriotic and Christian values is an example of process heading into the direction of illiberal trends. This form of political fetishism legitimises the erosion of democracy and pluralism, yet allows for existence of political opposition, something that distinguishes Polish case, for example, from the Hungarian one. However, illiberal trends in the context of, for instance the U.S., focuses on achieving "greatness". In the Polish settings, it focuses on the preservation and restitution of values that have allegedly been destroyed by Western influences and previous governments, also in realm of public media policy. Protection of the national community along with deterioration of media freedoms, political meddling, and over-reach are the characterising features of reactionary politics of media regulations in contemporary Poland. From this perspective, cultural narratives of nationhood are inherent elements of the process of politicisation of the public media in Poland executed via legislation and policy changes. 


\section{Disclosure statement}

No potential conflict of interest was reported by the authors.

\section{Notes on contributors}

Paweł Surowiec, PhD, is Senior Lecturer at the University of Sheffield, UK, specialising in strategic communication, public diplomacy and political campaigning in the context of European politics.

Magdalena Kania-Lundholm, PhD, is sociologist and works as a researcher at the Department of Sociology, Uppsala University, Sweden. Her research focuses on the intersections between culture, power and technology with particular focus on digital contexts.

Małgorzata Winiarska-Brodowska, PhD, is Assistant Professor at the Institute of Journalism, Media and Social Communication of the Jagiellonian University, Poland. She conducts research in the areas of European media, international public and political communication as well as civic participation.

\section{ORCID}

Paweł Surowiec (D) http://orcid.org/0000-0002-3554-9242

Magdalena Kania-Lundholm (10) http://orcid.org/0000-0002-7624-1033

Małgorzata Winiarska-Brodowska (D) http://orcid.org/0000-0002-6518-6841

\section{References}

Bardoel, J., and L. d'Haenens. 2008. "Reinventing Public Service Broadcasting in Europe: Prospects, Promises and Problems." Media, Culture \& Society 30 (3): 337-335.

Barker, C., and D. Galasiński. 2007. Cultural Studies and Discourse Analysis: A Dialogue on Language and Identity. London: Sage.

Bennett, L., and B. Pfetsch. 2018. "Rethinking Political Communication in a Time of Disrupted Public Spheres." Journal of Communication 68 (2): 243-253.

Bermeo, N. 2016. "On Democratic Backsliding." Journal of Democracy 27 (1): 5-19.

Big Media Act (Draft). 2016. Projekt ustawy o mediach narodowych. Sejm. Accessed October 5, 2018. http://www.sejm.gov.pl/sejm8.nsf/druk.xsp?nr $=442$.

Braman, S. 2004. "Where Has Media Policy Gone? Defining the Field in the Twenty-First Century." Communication Law and Policy 9 (2): 153-182.

Broadcasting and Culture Commission. 2016. Pełny zapis przebiegu posiedzenia Komisji Kultury $i$ Środków Przekazu. Kancelaria Sejmu. Accessed October 5, 2018. http://orka.sejm.gov.pl/zapisy8. nsf/0/3B6DEACB4C2A859DC12580B10028FF26/\%24File/0062208.pdf.

Burchell, G. 1996. "Liberal Government and the Techniques of the Self." In Foucault And Political Reason, edited by A. Barry, T. Osborne, and N. Rose, 19-36. Chicago: Chicago University Press.

CBOS. 2016. Komunikat Z Badań: Finansowanie Mediów Publicznych. CBOS: Warszawa. Accessed September 5, 2018: https://www.cbos.pl/SPISKOM.POL/2016/K_066_16.PDF.

Chadwick, A. 2013. The Hybrid Media System: Politics and Power. Oxford: Oxford University Press.

Chapman, A. 2017. Pluralism Under Attack: The Assault on Press Freedom in Poland. New York: Freedom House.

Cianetti, L., J. Dawson, and S. Hanley. 2018. "Rethinking 'Democratic Backsliding' in Central and Eastern Europe - Looking Beyond Hungary and Poland." East European Politics 34 (3): 243-256.

Constitution of Poland. 1997. The Constitution of the Republic of Poland. Sejm. Accessed October 5 , 2018. http://www.sejm.gov.pl/prawo/konst/angielski/kon1.htm.

Dobek-Ostrowska, B. 2006. Media masowe $w$ demokratyzujących się systemach politycznych. $W$ drodze do wolności słowa i mediów. Wrocław: Wydawnictwo Uniwersytetu Wrocławskiego.

Dobek-Ostrowska, B. 2011. Polski system medialny na rozdrożu. Media w polityce, polityka w mediach. Wrocław: Wydawnictwo Uniwersytetu Wrocławskiego. 
Dobek-Ostrowska, B., and M. Głowacki, eds. 2015. Democracy and Media in Central and Eastern Europe 25 Years On. Frankfurt am Main: Peter Lang.

Foucault, M. 1972. The Archeology of Knowledge. London: Tavistock.

Foucault, M. 1980. "The Confession of the Flesh". In Power/Knowledge: Selected Interviews and Other Writings 1972-1977 by Michel Foucault, edited by C. Gordon, 194-228. New York: Pantheon Books.

Foucault, M. 1982. "The Subject and Power." Critical Inquiry 8 (4): 777-795.

Foucault, M. 1989. Résumé Des Cours 1970-1982. Paris: Juillard.

Freedman, D. 2008. The Politics Of Media Policy. Cambridge: Polity.

Garnham, N. 1998. "Policy." In The Media: An Introduction, edited by A. Briggs and P. Cobley, 210-223. London: Longman.

Głowacki, M. 2008. "Political Pressure on Public Television in Poland. The Case of the National Broadcasting Council." In Comparing Media Systems in Central Europe. Between Commercialization and Politicization, edited by B. Dobek-Ostrowska and M. Głowacki, 111-122. Wrocław: University of Wrocław Press.

Głowacki, M. 2015. "Governance of Public Media System in Poland: The Role of the Public." Media and Communication 3 (4): 26-34.

Goban-Klas, T. 1990. "Making the Media Policy in Poland." Journal of Communication 40 (1): 50-54.

Goban-Klas, T. 1996. "Politics Versus the Media in Poland: A Game Without the Rules." Journal of Communist Studies And Transition Politics 12 (4): 21-41.

Gross, P. 2002. Entangled Evolutions: Media and Democratization in Eastern Europe. Baltimore: Johns Hopkins University Press.

Gross, P. 2004. "Between Reality And Dream: Eastern European Media Transition, Transformation and Consolidation." East European Politics, Society \& Cultures 18 (1): 110-131.

Grzebalska, W., and A. Pető. 2018. "The Gendered Modus Operandi Of the Illiberal Transformation in Hungary and Poland." Women's Studies International Forum 68: 164-172.

Gulyás, A., and F. Hammer, eds. 2013. Public Service Media in the Digital Age: International Perspectives. Cambridge: Cambridge Scholars Publishing.

Hanley, S., and M. A. Vachudova. 2018. "Understanding the Illiberal Turn: Democratic Backsliding in the Czech Republic." East European Politics 34 (3): 276-296.

Jakubowicz, K. 2004. "Ideas In Our Heads: Introduction of PSB as Part of Media System Change in Central and Eastern Europe." European Journal of Communication 19 (1): 53-74.

Jakubowicz, K., and M. Sükösd. 2008. Finding the Right Place on the Map. Central and Eastern European Media Change in a Global Perspective. Bristol: Intellect Press.

Klimkiewicz, B. 2016. "Poland: The Public, The Government and The Media." LSE Media Policy Project Blog, Accessed July 30, 2018. http://blogs.Ise.ac.uk/mediapolicyproject/2016/02/08/poland-thepublic-the-government-and-the-media/.

Klimkiewicz, B. 2017. "State, Media and Pluralism: Tracing Roots and Consequences of the Media Policy Change in Poland." Publizistik 62 (2): 197-213.

Kubik, J. 2012. "Illiberal Challenge to Liberal Democracy." The Taiwan Journal of Democracy 8 (2): 79-89.

Lauk, E. 2009. "Reflections On Changing Patterns of Journalism In The New EU Countries." Journalism Studies 10 (1): 69-84.

Levy, J. 2006. The State After Statism: New State Activities in the Age of Liberalization. Cambridge: Harvard University Press.

Lilleker, D. 2014. Political Communication and Cognition. Basingstoke: Palgrave MacMillan.

National Media Council Act. 2016. Ustawa o Radzie Mediów Narodowych. Sejm. Accessed October 5, 2018. http://prawo.sejm.gov.pl/isap.nsf/DocDetails.xsp?id = WDU20160000929.

Nolan, D. 2006. "Media, Citizenship and Governmentality: Defining 'The Public' of Public Service Broadcasting." Social Semiotics 16 (2): 225-242.

Paletz, D., and K. Jakubowicz, eds. 2003. Business as Usual: Continuity and Change in Central and Eastern Europe. Cresskill: Hampton Press.

Pfetsch, B., and K. Voltmer. 2012. "Political Communication Cultures in Bulgaria and Poland." International Journal of Press/Politics 17 (4): 388-406.

Puchalska, B. 2005. "Polish Democracy in Transition?" Political Studies 53 (4): 816-832. 
Puppis, M. 2010. "Media Governance: A New Concept For The Analysis of Media Policy And Regulation." Communication, Culture \& Critique 3 (2): 134-149.

Sam, C. H. 2019. "Shaping Discourse Through Social Media: Using Foucauldian Discourse Analysis to Explore the Narratives That influence Educational Policy." American Behavioural Scientist. doi:10. $1177 / 0002764218820565$.

Shields, S. 2015. "Neoliberalism Redux: Poland's Recombinant Populism and its Alternatives." Critical Sociology 41 (4/5): 659-678.

Small Media Act. 2015. Ustawa o zmianie ustawy o radiofonii i telewizji. Sejm. Accessed October 5, 2018. http://prawo.sejm.gov.pl/isap.nsf/DocDetails.xsp?id = WDU20160000025.

Sparks, C. 2008. "Media Systems in Transition: Poland, Russia, China." Chinese Journal of Communication 1 (1): 7-24.

Stępka, P. 2010. "Public Service Broadcasting in Poland: Between Politics and Market." In Reinventing Public Service Communication, edited by P. losifidis, 233-244. Basingstoke: Palgrave MacMillan.

Štětka, V. 2012. "From Multinational to Business Tycoons: Media Ownership And Journalistic Autonomy in Central and Eastern Europe." The International Journal of Press/Politcs 17 (1): 433-456.

Streeter, T. 2013. "Policy, Politics and Discourse." Communication, Critique \& Culture 6 (1): 488-501.

Surowiec, P., and V. Štětka, eds. 2017. Social Media and Politics in Central and Eastern Europe. London: Routledge.

Szczepaniak, R., ed. 2011. Media Convergences: Experiences and Approaches. Frankfurt am Main: Peter Lang.

Zielonka, J., ed. 2015. Media And Politics in New Democracies: Europe in Comparative Perspective. Oxford: Oxford University Press.

\section{Appendix}

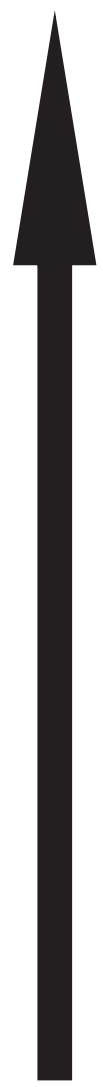

9 July 2018

PM states that $80 \%$ of Polish media landscape is in hands of the Government adversaries

\section{8}

31 December 2017 Announcement of further plans on media policy and de-concentration in media markets

11 December 2017 KRRiT imposes a financial penalty on a private broadcaster, TVN for reporting citizens' protests, and backtracks on this decision 10 January 2018

11 December 2017 Mateusz Morawiecki is appointed as the Prime Minister

30 August 2017 Media reports on a leaked proposal of the legal act on social media platforms

\section{7}

18 December 2016 Protests against the restriction of journalist privileges in reporting from the Sejm 22 June 2016 Introduction of the 'Act on the National Media Council'

30 June 2016 Decision to postpone the policy process initiated by 'Big Media Act' package

17 May 2016 Public hearing held by the Broadcasting and Culture Commission (the Sejm)

29 April 2016 First parliamentary debate on the 'Big Media Draft Act' in the Sejm

21 April 2016 'Big Media Act' was put forward setting out the orientation for public media policy: 'Draft Act on National Media'; 'Draft Act on Audiovisual Fees'; 'Draft Act on Provisions' (executive bills)

14 March 2016 Citizens' Pact for Public Media was signed

8 January 2016 Appointment of new public media directors; Jacek Kurski re-affirmed as the director of TVP

\section{6}

30 December 2015 'Small Media Act' voted through by the Sejm and introduced (expires 30 June 2016) 16 November 2015 Appointment of Beata Szydło Government 25 October 2015 PiS wins majority in the Sejm and Senate (Parliament)

2015

Figure A1. Timeline summarising the making of public media policy by the Law and Justice Government (2015-present). 